Iran Journal of Nursing (IJN)

Vol 34, No. 131, Aug 2021: 1- 6

\title{
"Letter to Editor"
}

\section{Challenges and Opportunities of Research during the COVID-19 Pandemic}

\author{
Azar Darvishpour ${ }^{1}$
}

\begin{abstract}
Dear editor
COVID-19 disease is an emerging phenomenon that is spreading rapidly around the world and has caused great concern to people around the $\operatorname{world}^{(1)}$. This epidemic has also created challenges for health services ${ }^{(2)}$. The result of this great epidemic is the filling of hospital beds, the extreme fatigue of medical teams, the severe shortage of personal protective equipment, the infection of hospital staff, the shortage of personnel, and the spread of disease and concerns in different countries of the world ${ }^{(3)}$. One of the challenges created during the Corona Pandemic is the reduction in the number of patients with dangerous non-covid diseases, including heart diseases, cancer, respiratory, kidney, and other diseases, referred to hospitals and medical centers. Patients with these diseases are not willing to refer to hospitals for treatment due to fear of getting infected with the coronavirus. This issue, on one hand, is one of the serious concerns of health officials regarding the health status of the people ${ }^{(4,5)}$, and on the other hand, it has affected other areas of the health system, including research.
\end{abstract}

Regarding the importance and status of research, there is no doubt that research is important and vital for society ${ }^{(6)}$. Sustainable and comprehensive development in any country significantly depends on the quantitative and qualitative expansion of research activities in that country ${ }^{(7)}$. According to the evidence, before the outbreak of coronavirus disease, some issues such as shortage of funds for research, failure of financial support for research projects, cumbersome administrative regulations (bureaucracy), lack of clear rules for evaluating research activities, and limited use of research results were among the research barriers in the country ${ }^{(6-8)}$. The outbreak of Coronavirus disease has also posed research challenges. One of these challenges is the limitation of easy access to research samples.

In fact, the decrease in hospitalization of patients in medical centers has made sampling difficult and limited for many studies performed in the clinical environment. Also, specialized wards of hospitals, which were the most important sampling center of most clinical trials, were changed to coronavirus wards ${ }^{(9)}$ and this also prevented access to research samples other than coronavirus samples. On the other hand, the outbreak of coronavirus disease, limited travel, and closure of dormitories ${ }^{(10)}$ have caused sampling challenges in the dissertations of graduate students.

Although the coronavirus pandemic imposed many problems on all indicators of society, including public health, it was an opportunity that led to the flourishing of some capabilities in the country such as the pervasiveness and development of virtual education. During the coronavirus pandemic, the authorities became more and more aware of the importance of distance education and e-learning, and it seems that virtual education in our country has entered a new phase ${ }^{(11)}$. The opportunity created by the virtualization of activities due to the spread of

\footnotetext{
${ }^{1}$ Department of Nursing, Social Determinants of Health (SDH) Research Center, Zeynab (P.B.U.H) School of Nursing and Midwifery, Guilan University of Medical Sciences, Rasht, Iran （Corresponding author) Tel: $\mathbf{+ 9 8 1 3 4 2 5 3 6 2 6 2}$ Email: darvishpour@gums.ac.ir
} 
the coronavirus has facilitated some activities in academic centers ${ }^{(12)}$. In addition to improving services to patients diagnosed with coronavirus disease, the e-learning platform can be a fertile ground for conducting research. The significant increase in the number of approved research projects and scientific research articles published by faculty members ${ }^{(13)}$ indicates more attention to research during coronavirus pandemic. It is possible to perform all kinds of quantitative, qualitative, and even interventional research in virtual environments. The use of virtual questionnaires can reduce sampling problems in most studies ${ }^{(14)}$. Conducting research in virtual environment is financially inexpensive, and with a little creativity, a national survey can be done at a reasonable cost and financial support ${ }^{(15)}$. Different platforms such as in-app training ${ }^{(16)}$ can be used for different interventions such as health staff and clients' virtual training. The data obtained from the virtual research do not need to be re-entered into data analysis software and are entered directly from the survey platform into data analysis software such as SPSS (Statistical Package for the Social Science), AMOS (Analysis of Moment Structures), LISREL (Linear Structural Relationships), etc. In this way, online research reduces workload and provides faster and better access to resources and information. Due to the assumed anonymity in virtual environment, the probability of the respondents' honesty in researches ${ }^{(15)}$ that examine sensitive and personal issues increases and creates a space almost free of any bias.

On the other hand, with the spread of this epidemic around the world, new technologies such as e-health can help patients and health care providers, and can also lead to the development of research. E-Health is a combination of electronic communications and health information technology. This term can include a wide range of services/systems in the field of medicine/healthcare and information technology, such as electronic health records, electronic prescriptions, telemedicine or telephone medicine, m-Health and more ${ }^{(17)}$. The data from these technologies can help research development. Therefore, with the development of necessary infrastructure such as the global Internet network and an increase in its speed, the development of interactive learning software, and the use of new technologies such as e-health, we will see the growing prosperity of virtual research in the country. This type of research should be continued alongside prevalent researches even after the termination of COVID-19.

In addition to the virtual background, the development of home care services can also help research development. Home care services can support health services and reduce the burden on the health system ${ }^{(18)}$. Although the outbreak of COVID-19 disease has created many problems and challenges for providing services in this area ${ }^{(19)}$, the development of home care services during the outbreak of COVID-19 makes it possible to conduct research in real environments like before the coronavirus pandemic, and researchers who face challenges in conducting virtual researches for different reasons, can use this platform.

In conclusion, it seems that great steps must be taken to address the barriers and challenges of research at this time, given the continuing widespread prevalence of COVID-19 disease. Therefore, it is suggested that politicians, officials, and health care planners consider the challenges and use the opportunities created by COVID-19 disease, to provide the necessary ground for the development of research in the country.

Keywords: Challenges, Research, COVID-19 Pandemic

\section{Conflict of Interest: No}

How to Cite: Darvishpour A. "Letter to Editor" Challenges and Opportunities of Research during the COVID19 Pandemic. Iran Journal of Nursing. 2021; 34(131):1-6. 


\title{
《أفه به سر دبير》
}

\section{فرصتها و جالشهاى يخوهش در دوران ياندمى كوويد-19}

\author{
آذر درويش يور'
}

بيمارى كوويد-19 (COVID-19) بديدهى نوظهورى است كه با سرعت بسيار زيادى در سراسر جهان در حال كسترش است

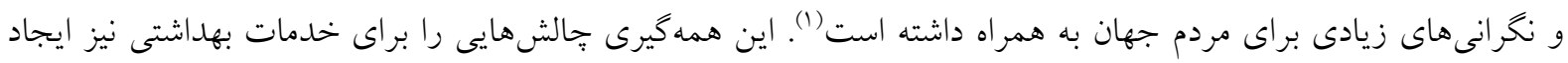

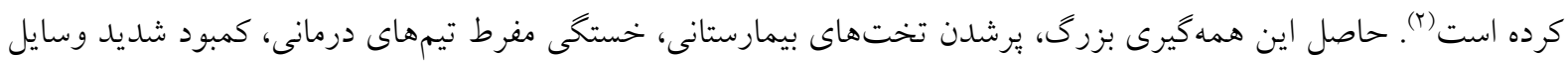

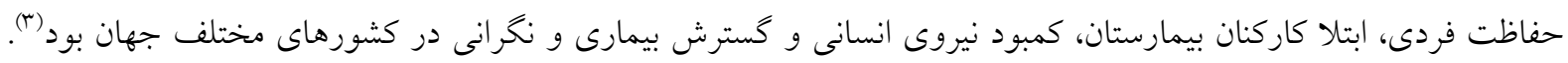
يكى از خالشهاى ايجاد شده در دوران ياندمى كوويد-19، كاهش مراجعه بيماران مبتلا به بيمارىهاى خطرناك غيركرونايى از جمله بيماران مبتلا به بيمارىهاى قلبى، سرطان، تنفسى، كليوى و ديغر بيمارىها به بيمارستانها و مراكز درمانى است و مبتلايان به اين بيمارىها از ترس ابتلا به كوويد-19 حاضر به مراجعه و ادامه درمان در بيمارستانها نيستند. اين موضوع نه تنها يكى از

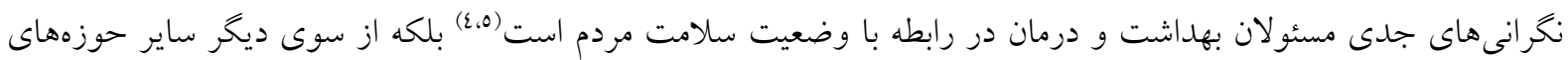

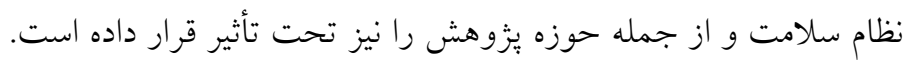

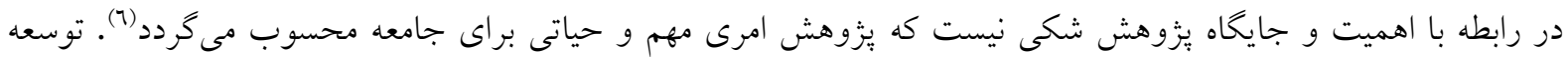

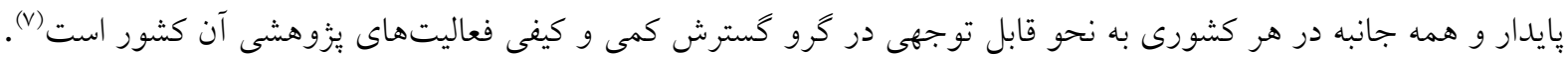

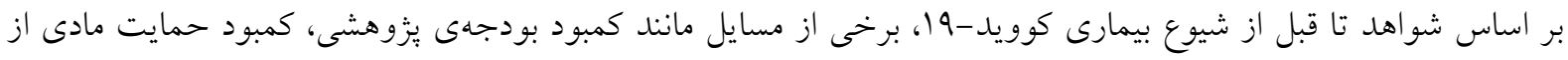

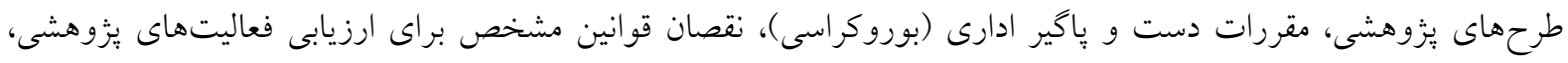

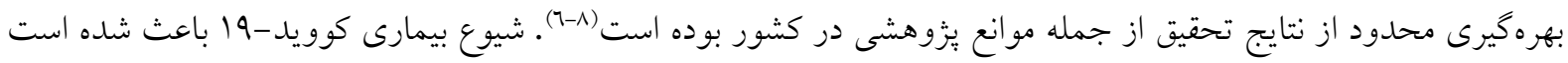

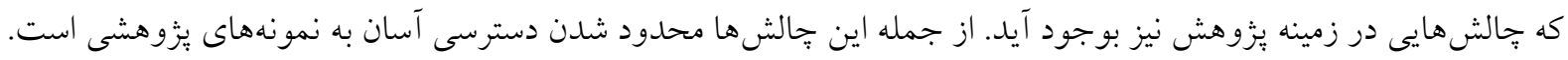

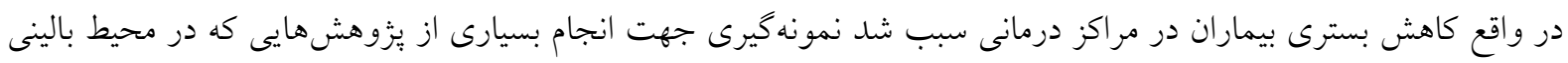

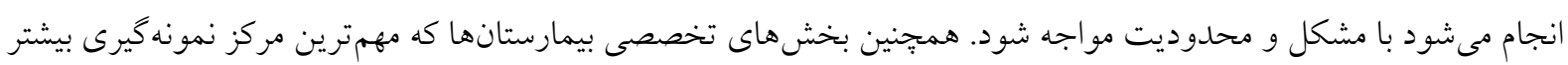

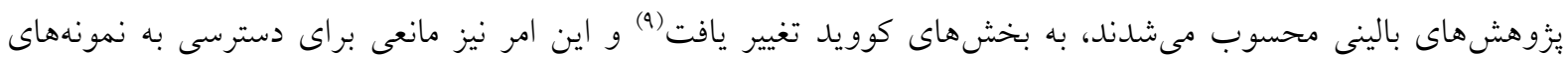

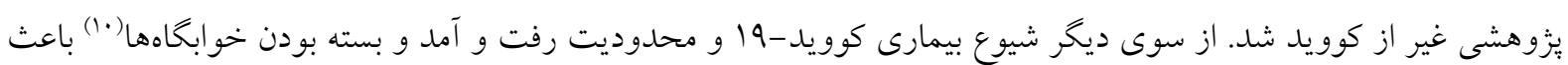

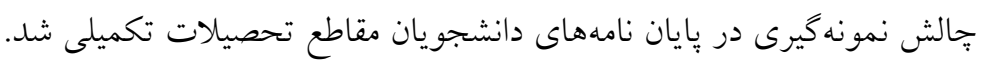

'. كروه يرستارى، مركز تحقيقات عوامل اجتماعى مؤثر بر سلامت، دانشكده برستارى و مامايى زينب (س)، دانشَاه علوم يزشكى كَيلان، رشت، ايران 
با وجود خالشهاى ذكر شده، اكر جهه ياندمى كوويد-19 1، مشكلات زيادى بر تمام شاخصهاى جامعه از جمله سلامت مردم

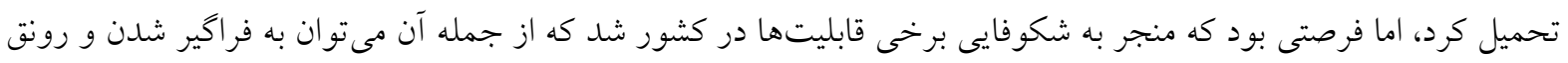

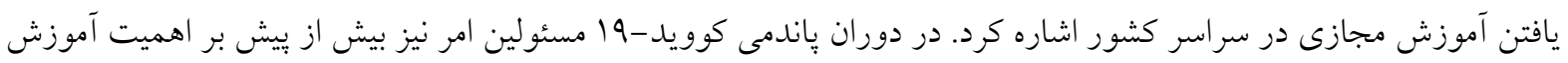

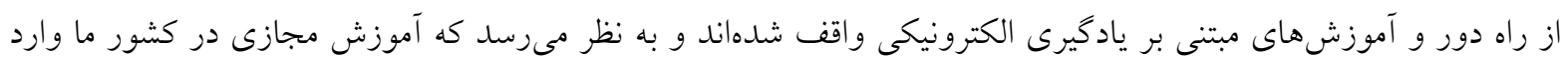

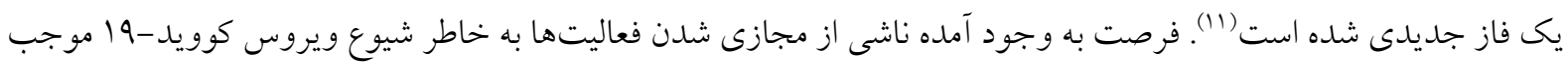

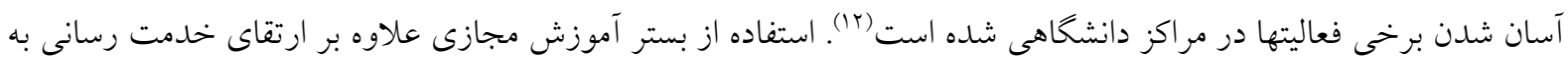

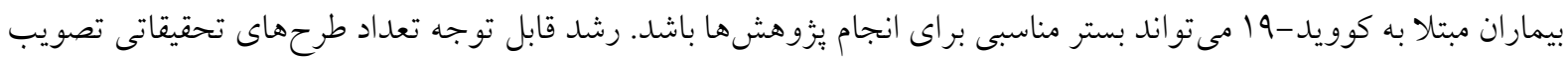

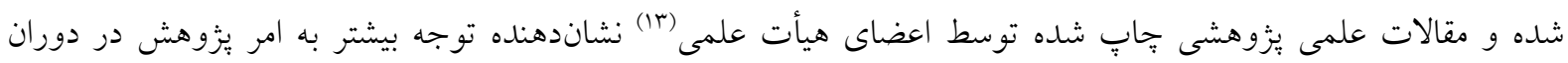

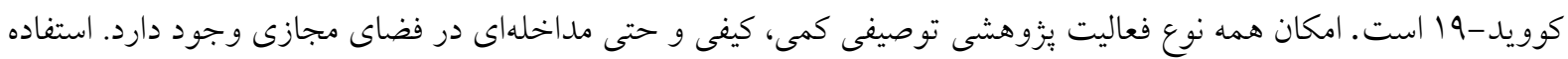

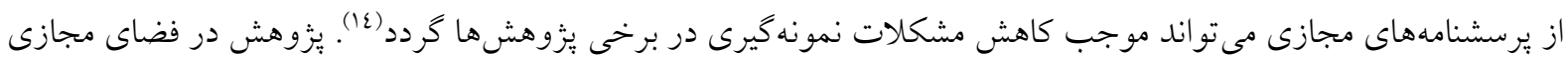

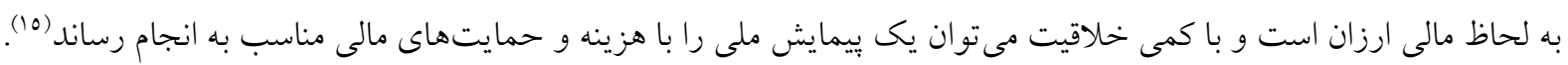

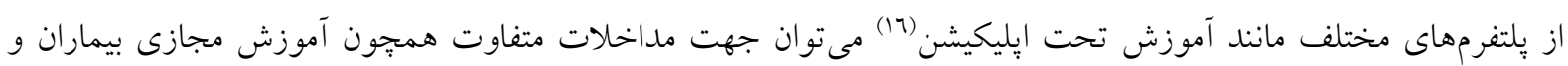

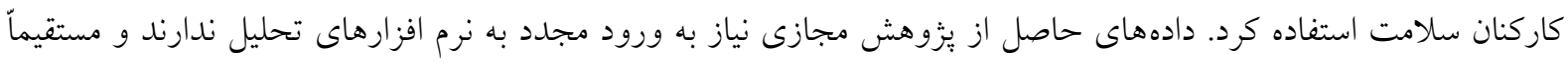

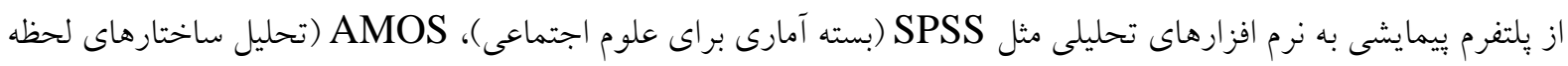

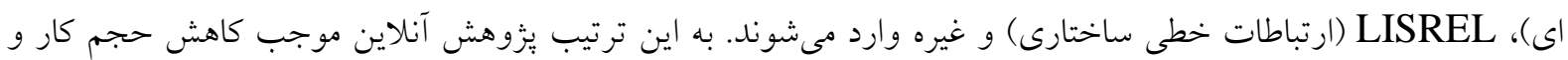

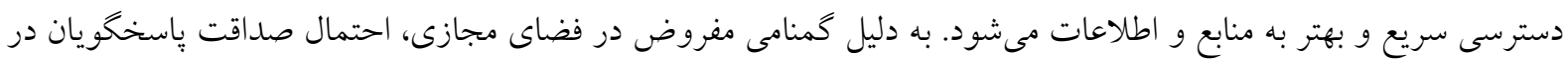

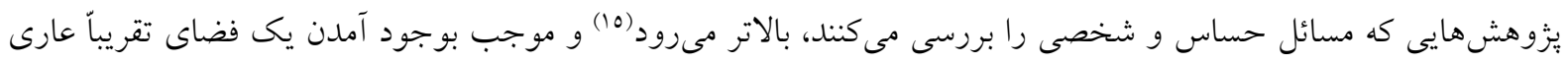

$$
\text { از هركونه سو خيرى مىشود. }
$$

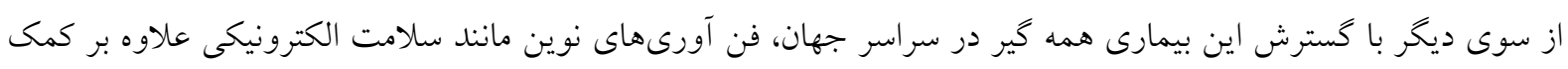

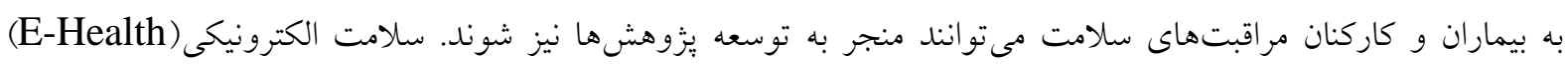

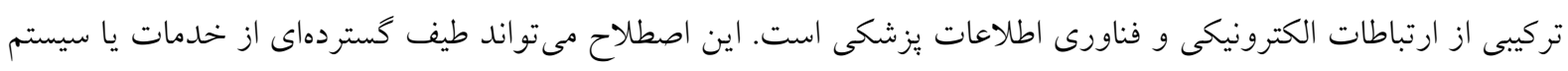

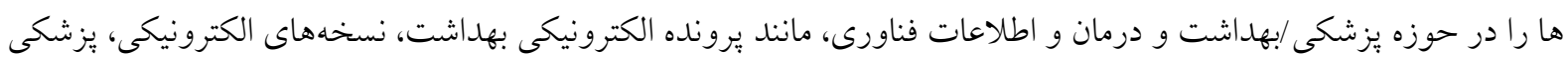

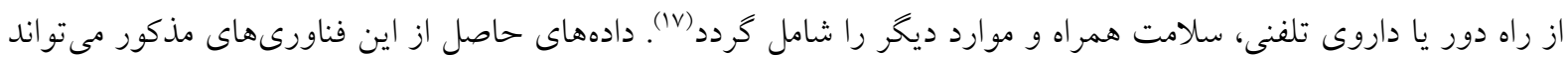

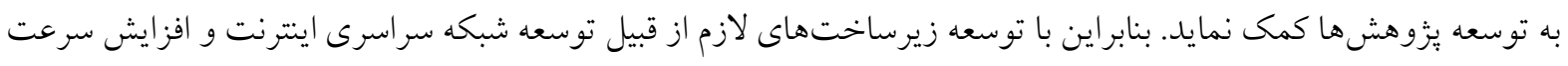

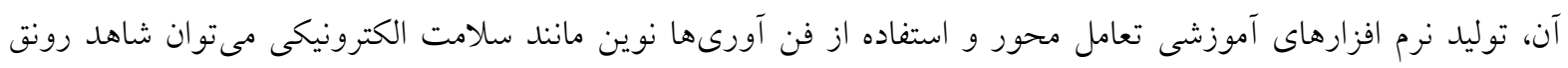

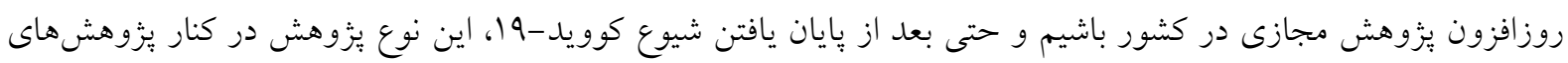
رايج تداوم داشته باشد. علاوه بر بستر مجازى با توسعه خدمات مراقبت در منزل نيز مى توان به توسعه يُزوهش كمك نمود. خدمات مراقبت در منزل

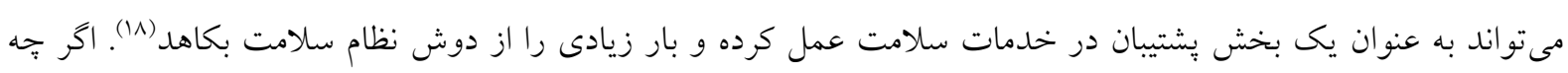

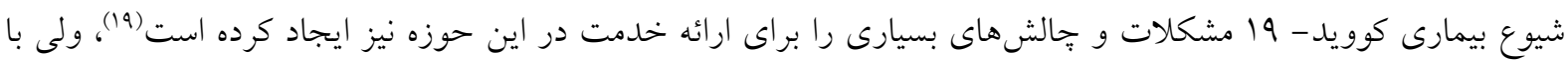

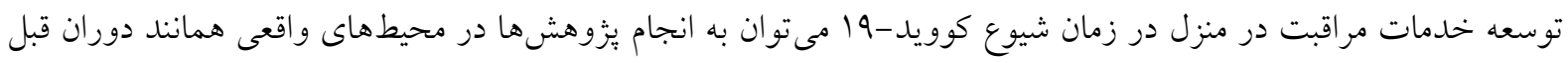

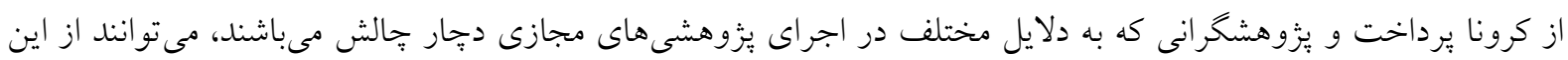
بستر نهايت استفاده را ببرند. 


$$
\begin{aligned}
& \text { در بايان و به عنوان جمع بندى، به نظر مىرسد در حال حاضر با توجه به ادامه دار بودن شيوع گستردمى بيمارى كوويد- } 19
\end{aligned}
$$

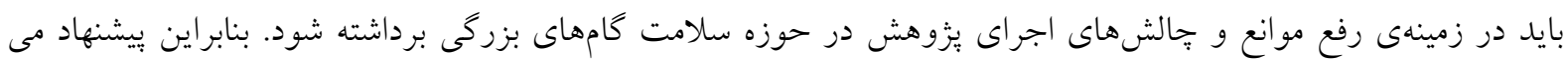

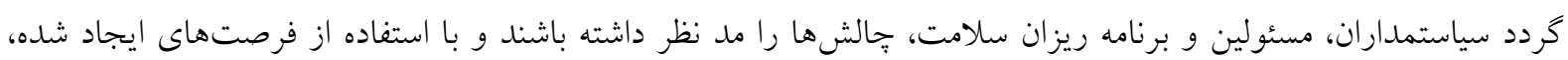

$$
\begin{aligned}
& \text { زمينه لازم جهت توسعه يُوهش در كشور را فراهم نمايند. }
\end{aligned}
$$

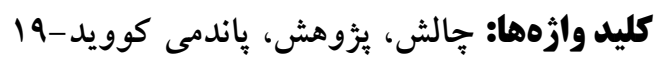

$$
\text { تاريخ داريخ يذيرش: تافئ: }
$$

\section{References}

1. Chan EY, Gobat N, Kim JH, Newnham EA, Huang Z, Hung H, Dubois C, Hung KK, Wong EL, Wong SY. Informal home care providers: the forgotten health-care workers during the COVID-19 pandemic. The Lancet. 2020;395(10242):1957-9.

2. Sterling MR, Tseng E, Poon A, Cho J, Avgar AC, Kern LM, Ankuda CK, Dell N. Experiences of home health care workers in New York City during the coronavirus disease 2019 pandemic: a qualitative analysis. JAMA internal medicine. 2020;180(11):1453-9.

3. Ministry of Health and Medical Education. National Instructions of New Coronavirus (nCoV2019). Version February 2020. Available from: http://medcare.behdasht.gov.ir/uploads/guild_line_corona_v2.pdf

4. Maziar P, Razavi S, Ghavamabad LH. Letter to editor: Covid-19 and dealing with it-lessons learned in Iran. Medical Journal of the Islamic Republic of Iran. 2020;34:110. [Persian]

5. IRNA. Corona and patients' fear of going to hospitals in Hormozgan. Retrieved 21 July, 2020, Available from: https://www.irna.ir/news/83862485/

6. Aboutalebi N. Investigating the obstacles and challenges of research in the education system and the role of research in improving and developing the country's education system. Afaq Humanities. 2020; 4(41): 67-84. [Persian]

7. Ramezani SG, Mehni O, Azizi N. Investigate the Barriers and Factors Influencing Inefficiency of Research at Farhangian University: A Grounded Theory Approach. J Management and Planning In Educational System. 2018;11(2):27-50. [Persian]

8. Asadi A, Savari M, Shokati Amghani M, Rezaie A, Ranjbar A, Zarie M. Challenges of Qualitative Researches in Agricultural Extension and Development Studies from the Viewpoint of Professors and Ph. D. Students of the Faculty of Economics and Agricultural Development of Tehran University. Journal of Agricultural Education Administration Research. 2018;10(45):98-115. [Persian]

9. Jebelli B, Varahram M, Soltanifard Razlighi M, Palizdar M, Ghazanchaei E. Management Strategies to Control the COVID-19 Crisis in Masih Daneshvari Hospital, Tehran, Iran. Journal Mil Med. 2020;22(6):616-22. [Persian]

10. Shahyad SH, Mohammadi MT. Psychological impacts of Covid-19 outbreak on mental health status of society individuals: a narrative review. Journal of Military Medicine. 2020;22(2):184-92. [Persian]

11. Ghafourifard M. The promotion of Virtual Education in Iran: The Potential which Turned into reality by Coronavirus. Iranian Journal of Medical Education. 2020;20:33-4. [Persian] 
12. Bagheri M. Report on virtual education at Arak University during the Corona .Neda (Scientific and cultural journal of Arak University). 2021;6(12):1-20. [Persian]

13. Mehr news report. Corona did not oppose Iran's scientific growth / Statistics of scientific documents in the days of Corona. Available from: https://www.mehrnews.com/news/5182206/\%DA\%A9\%D8\%B1\%D9\%88\%D9\%86\%D8\%A7\%D8\%AD\%D8\%B1\%DB\%8C\%D9\%81-\%D8\%B1\%D8\%B4\%D8\%AF\%D8\%B9\%D9\%84\%D9\%85\%DB\%8C-\%D8\%A7\%DB\%8C\%D8\%B1\%D8\%A7\%D9\%86\%D9\%86\%D8\%B4\%D8\%AF-\%D8\%A2\%D9\%85\%D8\%A7\%D8\%B1\%D9\%85\%D8\%B3\%D8\%AA\%D9\%86\%D8\%AF\%D8\%A7\%D8\%AA\%D8\%B9\%D9\%84\%D9\%85\%DB\%8C-\%D8\%AF\%D8\%B1$\% \mathrm{D} 8 \% \mathrm{~B} 1 \% \mathrm{D} 9 \% 88 \% \mathrm{D} 8 \% \mathrm{~B} 2 \% \mathrm{D} 9 \% 87 \% \mathrm{D} 8 \% \mathrm{~A} 7 \% \mathrm{DB} \% 8 \mathrm{C}-$ \%DA\%A9\%D8\%B1\%D9\%88\%D9\%86\%D8\%A7

14. Jamali HR. Use of electronic questionnaires in survey research. Iran Pajouhan. Available from: http://www.iranresearches.ir/\%D8\%AF\%D8\%A7\%D9\%86\%D9\%84\%D9\%88\%D8\%AF\%D8\%B1\%D8\%A7\%D9\%8A\%DA\%AF\%D8\%A7\%D9\%86\%D8\%AE\%D8\%A8\%D8\%B1\%D8\%AE\%D9\%88\%D8\%A7\%D9\%86-2/536\%D8\%A7\%D8\%B3\%D8\%AA\%D9\%81\%D8\%A7\%D8\%AF\%D9\%87-\%D8\%A7\%D8\%B2\%D9\%BE\%D8\%B1\%D8\%B3\%D8\%B4\%D9\%86\%D8\%A7\%D9\%85\%D9\%87$\% \mathrm{D} 9 \% 87 \% \mathrm{D} 8 \% \mathrm{~A} 7 \% \mathrm{D} 9 \% 8 \mathrm{~A}-$ \%D8\%A7\%D9\%84\%D9\%83\%D8\%AA\%D8\%B1\%D9\%88\%D9\%86\%D9\%8A\%D9\%83\%D9\%8A\%D8\%AF\%D8\%B1-\%D9\%BE\%DA\%98\%D9\%88\%D9\%87\%D8\%B4\%D9\%87\%D8\%A7\%D9\%8A\%D9\%BE\%D9\%8A\%D9\%85\%D8\%A7\%D9\%8A\%D8\%B4\%D9\%8A.html

15. Iranian Association for World Studies. A meeting on "Research in Cyberspace" was held. Forum News 7.2017. Available from: http://iwsa.ir/content/688/\%D9\%86\%D8\%B4\%D8\%B3\%D8\%AA\% $2 \%$ AB\%D9\%BE\%DA\%98\%D9\%88\%D9\%87\%D8\%B4-\%D8\%AF\%D8\%B1\%D9\%81\%D8\%B6\%D8\%A7\%DB\%8C-\%D9\%85\%D8\%AC\%D8\%A7\%D8\%B2\%DB\%8C\%C2\%BB\%D8\%A8\%D8\%B1\%DA\%AF\%D8\%B2\%D8\%A7\%D8\%B1-\%D8\%B4\%D8\%AF

16. Shokrbaghani A S. Introducing educational platforms (platform) suitable for virtual education. Institute of Educational Studies, 2020. Available from: http://oerp.ir/baztab/11260/\%D9\%85\%D8\%B9\%D8\%B1\%D9\%81\%DB\%8C\%D8\%A8\%D8\%B3\%D8\%AA\%D8\%B1\%D9\%87\%D8\%A7\%DB\%8C\%D8\%A2\%D9\%85\%D9\%88\%D8\%B2\%D8\%B4\%DB\%8C\%D9\%BE\%D9\%84\%D8\%AA\%D9\%81\%D8\%B1\%D9\%85\%D9\%85\%D9\%86\%D8\%A7\%D8\%B3\%D8\%A8-\%D8\%A2\%D9\%85\%D9\%88\%D8\%B2\%D8\%B4\%D9\%85\%D8\%AC\%D8\% A7\%D8\%B2\%DB\%8C

17. Hoseini E, Zare F. Application of e-health in the Corona virus's (COVID-19) pandemic. Journal of Community Health Research. 2020;9(2):66-8. [Persian]

18. Keyvanloo Shahrestanaki S. "Letter to Editor" Challenges of Home Care during the COVID-19 Outbreak. Iran Journal of Nursing. 2020;33(127):1-6. [Persian]

19. Shang J, Chastain AM, Perera UG, Quigley DD, Fu CJ, Dick AW, Pogorzelska-Maziarz M, Stone PW. COVID-19 preparedness in US home health care agencies. J Am Med Dir Assoc. 2020;21(7):924-7. 